\title{
Predictive Value of Sphingosine Kinase 1 Expression in Papillary Thyroid Carcinoma
}

\author{
SUNG-IM DO ${ }^{1}$, HYUN-SOO KIM ${ }^{2}$, KYUNGEUN KIM ${ }^{1}$, HYUNJOO LEE ${ }^{1}$, \\ IN-GU DO ${ }^{1}$, DONG-HOON KIM ${ }^{1}$, SEOUNG WAN CHAE ${ }^{1}$ and JIN HEE SOHN ${ }^{1}$ \\ ${ }^{1}$ Department of Pathology, Kangbuk Samsung Hospital, Sungkyunkwan \\ University School of Medicine, Seoul, Republic of Korea; \\ ${ }^{2}$ Department of Pathology, Severance Hospital, Yonsei University College of Medicine, Seoul, Republic of Korea
}

\begin{abstract}
Background/Aim: Sphingolipid metabolites are emerging as key signaling molecules in cancer. Sphingosine kinase 1 is up-regulated in many different types of human malignancies and plays a crucial role in cancer development and progression. The utility of sphingosine kinase 1 to act as a predictive biomarker in thyroid cancer remains unclear. Materials and Methods: Sphingosine kinase 1 expression was evaluated using immunohistochemical staining in 110 formalin-fixed, paraffin-embedded papillary thyroid carcinoma tissue samples. Results: Sphingosine kinase 1 expression in papillary thyroid carcinoma tissue was significantly higher than in nodular goiter $(p<0.001)$ or normal thyroid $(p<0.001)$ tissue. Sphingosine kinase 1 was observed in the cytoplasm of tumor cells. Thirty-four (30.9\%) of 110 papillary thyroid carcinomas exhibited high sphingosine kinase 1 expression, that was significantly associated with tumor multiplicity ( $p=0.004)$, extrathyroidal extension ( $p=0.013)$, presence of lymph node metastasis $(p<0.001)$, and number of metastatic lymph nodes $(p=0.042)$. In addition, high sphingosine kinase 1 expression was the only independent predictor of lymph node metastasis $(p<0.001)$. Conclusion: Sphingosine kinase 1 is involved in papillary thyroid carcinoma development and progression and can serve as a potential biomarker predictive of lymph node metastasis.
\end{abstract}

This article is freely accessible online.

Correspondence to: Hyun-Soo Kim, Department of Pathology, Severance Hospital, Yonsei University College of Medicine, 50-1, Yonsei-ro, Seodaemun-gu, Seoul 03722, Republic of Korea. Tel: +82 222281794, +82 23620860, e-mail: hyunsookim@yuhs.ac

Key Words: Thyroid, papillary thyroid carcinoma, sphingosine kinase 1 , immunohistochemistry, lymph node metastasis.
Thyroid cancer is the most commonly diagnosed endocrine malignancy. Papillary thyroid carcinoma constitutes approximately $90 \%$ of all malignant thyroid neoplasms, generally with an indolent clinical course (1-3). Long-term outcomes of patients with papillary thyroid carcinoma are favorable, with a survival rate $>90 \%$ (1). However, some papillary thyroid carcinoma cases display aggressive oncogenic behavior, and clinicopathological characteristics such as old age, large tumor size, extrathyroidal extension, and cervical lymph node metastasis have been suggested as factors for a poor prognosis (4-6). Similar to other human cancers, papillary thyroid carcinoma development, progression, and metastasis are caused by numerous genetic, reproductive, and environmental factors (3). Although many researchers have suggested potential biomarkers for papillary thyroid carcinoma to predict aggressive oncogenic behavior, no reliable biomarker has been identified. There is an urgent need to establish a predictive indicator to identify patients at high risk of metastasis and to enable clinicians to tailor therapeutic strategies to such patients and improve their outcomes (7).

Metastasis, a principal cause of cancer-related death, presents an important study target. In many human cancers, metastasis to the regional lymph node is one of the most significant predictors of patient outcome $(8,9)$. Lymph node metastasis is associated with decreased papillary thyroid carcinoma survival and increased risk of local recurrence. Outcome data from large institutional cohorts have shown a significant and independent negative impact of lymph node metastasis on outcomes in papillary thyroid carcinoma (10-12).

Sphingolipid metabolites are emerging as key signaling molecules in cancer $(13,14)$. Sphingolipid metabolism enzymes, sphingolipid-binding proteins, and transmembrane transporters of sphingolipid metabolites have important roles in cancer pathophysiology (15). Sphingosine kinases are important in cancer growth due to their ability to prevent apoptosis and stimulate cell proliferation and angiogenesis $(14,16)$. Two sphingosine kinase isoenzymes, sphingosine 
kinase 1 and 2, have been identified in humans (17). Sphingosine 1-phosphate, a sphingolipid metabolite whose formation is catalyzed by sphingosine kinase 1, plays a crucial role in cell survival, growth, proliferation, and apoptosis (18).

Sphingosine kinase 1 is upregulated in cancers of the brain $(19,20)$, head and neck $(18)$, colon $(21,22)$, stomach (16), ovaries (23), cervix (14), and lungs (24). Sphingosine kinase 1 is involved in cancer development, progression, metastasis, and neovascularization in the tumor microenvironment (25). However, data on sphingosine kinase 1 expression in thyroid cancer are limited. In this study, we analyzed the expression of sphingosine kinase 1 in papillary thyroid carcinoma tissue samples using a tissue microarray technique and immunohistochemical staining. In addition, we investigated the associations between sphingosine kinase 1 expression and clinicopathological characteristics of papillary thyroid carcinoma patients. Our observations suggest that sphingosine kinase 1 is involved in papillary thyroid carcinoma development and progression and can be useful as a predictive biomarker for lymph node metastasis.

\section{Materials and Methods}

Tissue specimens. This study (2017-08-017) was reviewed and approved by the Institutional Review Board of Kangbuk Samsung Hospital (Seoul, Republic of Korea). We selected 110 cases of papillary thyroid carcinoma and 16 cases of nodular goiter from the archival cases in the Kangbuk Samsung Hospital (Seoul, Republic of Korea). Eighty-one normal thyroid tissue samples were obtained from patients who had given informed consent and were used as controls. Tissues resected by surgeons were examined by pathologists before fixation in $10 \%$ neutral-buffered formalin. After fixation for $12-24 \mathrm{~h}$, the tissues were thoroughly examined macroscopically and sectioned. After automatic tissue processing, sections were embedded in paraffin blocks. Four-micrometer-thick slices were cut from each formalinfixed, paraffin-embedded tissue block using a rotary microtome, stained with hematoxylin and eosin, covered with a glass coverslip, and sent to two board-certified pathologists for examination and pathological diagnosis. Clinical and pathological information were obtained from the pathology reports as well as from electrical medical information systems. The information collected included age and sex of the patient, multiplicity and greatest dimension of tumor, presence of extrathyroidal extension and lymph node metastasis, number of metastatic lymph nodes, and $B R A F$ mutational status.

Tissue microarray construction. Tissue microarray blocks were constructed as described previously (7). Briefly, all hematoxylin and eosin-stained slides were reviewed, and the two most representative tumor areas were marked on the corresponding formalin-fixed, paraffin-embedded tissue blocks. Two 2-mm-diameter tissue cores were obtained from each block and manually arrayed into recipient tissue microarray blocks. The assembly was held in an X-Y position guide with a $1-\mathrm{mm}$ increment between individual cores, and the instrument was used to create holes in a recipient block with defined array cores. A needle was used to transfer the cores into the recipient block. The percentage of tumor volume in each core was $>70 \%$. Two tissue microarray blocks were prepared for each case.
Immunohistochemical staining. Immunohistochemical staining was performed using a compact polymer method (Bond Intense Detection Kit, Leica Biosystems, Newcastle upon Tyne, UK) (3, 7, 14, 26-30). The 4- $\mu$ m-thick, formalin-fixed, paraffin-embedded slices were deparaffinized and dehydrated with xylene and then rehydrated in a graded series of alcohol solutions. Endogenous peroxidase activity was halted by incubation with $0.3 \%$ hydrogen peroxide and methanol for $20 \mathrm{~min}$. Following a rinse in phosphatebuffered saline, slices were processed in citrate buffer $(0.01 \mathrm{M}, \mathrm{pH}$ 6.0) and then irradiated in a microwave oven for $20 \mathrm{~min}$ and allowed to cool at room temperature. The primary antibody used was anti-SPHK1 antibody (1:100, polyclonal, Abgent, San Diego, CA, USA). After chromogenic visualization using a Dako Peroxidase/DAB EnVision+ Detection System (Dako, Agilent Technologies, Carpinteria, CA, USA), slices were counterstained with hematoxylin and coverslipped. Negative controls were stained without primary antibody.

Interpretation of immunohistochemical staining. The degree of sphingosine kinase 1 expression was evaluated by multiplying scores for the proportion of positively stained cancer cells and staining intensity $(14,20,31)$. The proportion of stained cancer cells was scored as: 0 , none; $1,1-9 \% ; 2,10-49 \% ; 3, \geq 50 \%$ of all cancer cells. Staining intensity was scored as: 0 , absent; 1 , weak; 2 , moderate; 3 , strong. The final score was calculated as the product of proportion and intensity score, resulting in scores of $0,1,2,3,4,6$, and 9 . The optimal cutoff value for high sphingosine kinase 1 expression was determined as described previously (14). A final score $\geq 4$ was used to define high sphingosine kinase 1 expression. All slides were examined and scored by two board-certified pathologists who were blinded to the clinicopathological data and patient identity. Disagreements between the pathologists were resolved by consensus.

Detection of BRAF mutation. For detection of the BRAF V600E mutation, nucleic acids from fresh thyroid tissue were isolated using a DNeasy Blood and Tissue Kit (Qiagen, Hilden, Germany) (3). Isolated nucleic acids were mixed with a polymerase chain reaction (PCR) master mix from a Seeplex BRAF V600E ACE Detection Kit (Seegene, Seoul, Republic of Korea). The mixed samples were immediately placed in a preheated thermal cycler for $15 \mathrm{~min}$, and PCR was carried out in a GeneAmp PCR System 9700 (Applied Biosystems, Foster City, CA, USA). The cycling amplification program consisted of 35 cycles of denaturation for $30 \mathrm{~s}$ at $94^{\circ} \mathrm{C}$, annealing for $30 \mathrm{~s}$ at $63^{\circ} \mathrm{C}$, and extension for $1 \mathrm{~min}$ at $72^{\circ} \mathrm{C}$. Amplified PCR products were loaded onto a $2 \%$ agarose gel and visualized with a SafeView Nucleic Acid Stain (Applied Biological Materials, Richmond, BC, Canada). The BRAF mutation was detected using a Gel Documentation System (Bio-Rad Laboratories, Hercules, CA, USA).

Statistical analysis. Chi-square or Fisher's exact test was performed to compare the frequency of high sphingosine kinase 1 expression between papillary thyroid carcinoma, nodular goiter, and normal thyroid tissue and to analyze associations between sphingosine kinase 1 expression status and clinicopathological characteristics. Multivariate logistic regression analysis with a backward stepwise elimination method was used to identify independent predictors of lymph node metastasis. Statistical analyses were performed using PASW Statistics (version 18.0; IBM SPSS, Chicago, IL, USA). Statistical significance was defined as a $p$-value less than 0.05 . 


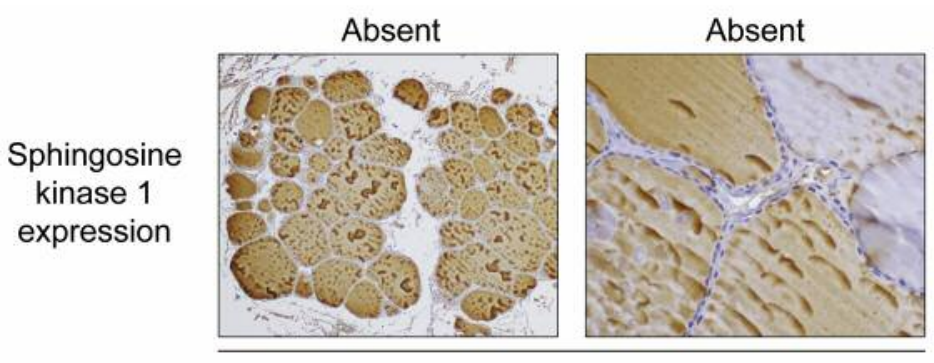

Normal thyroid tissue
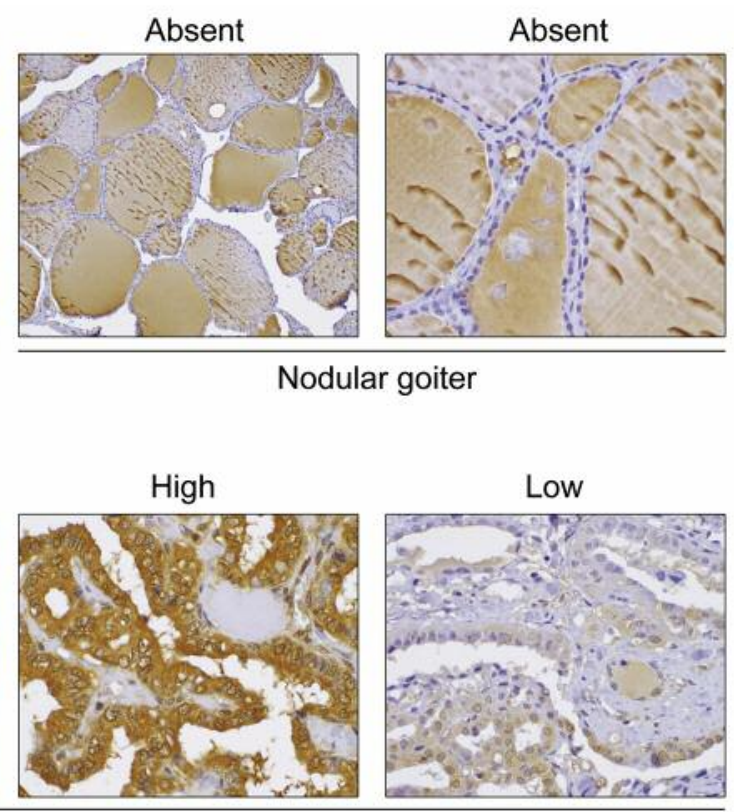

Normal thyroid

Papillary thyroid carcinoma

tissue

Figure 1. Immunohistochemical expression of sphingosine kinase 1 in normal thyroid, nodular goiter, and papillary thyroid carcinoma tissue. None of the follicular epithelial cells in normal thyroid tissue or nodular goiter showed sphingosine kinase 1 immunoreactivity. In contrast, papillary thyroid carcinoma tissue exhibited high or low cytoplasmic sphingosine kinase 1 expression. The compact polymer method was used.

\section{Results}

Patient demographics. Patient age ranged from 23-73 years (median $=43$ years). Seventy-five $(68.2 \%)$ of the 110 patients were women. The mean tumor size was $0.95 \mathrm{~cm}$ (range $=0.2-$ $5.5 \mathrm{~cm})$, and 71 cases $(64.5 \%)$ were diagnosed as microcarcinomas $(<1.0 \mathrm{~cm})$. Multifocal tumors and extrathyroidal tumor extension were noted in $26(23.6 \%)$ and $55(50.0 \%)$ cases, respectively. Lymph node metastases were identified in $64(58.2 \%)$ patients. Thirty-three $(51.6 \%)$ of 64 patients with lymph node metastases had three or more metastatic lymph nodes. BRAF mutational analysis was performed in $70(63.6 \%)$ cases, $58(82.9 \%)$ of which were positive.

Sphingosine kinase 1 expression. Representative photomicrographs of sphingosine kinase 1 expression in normal thyroid, nodular goiter, and papillary thyroid carcinoma tissue are shown in Figure 1. Sphingosine kinase 1 immunoreactivity was absent in all 81 normal thyroid tissues (Table I). No staining was observed in $12(75.0 \%)$ of the 16 nodular goiter tissue samples, and the remaining four nodular goiter samples exhibited faint sphingosine kinase 1 expression in the cytoplasm of bland-appearing follicular epithelial cells. In contrast, papillary thyroid carcinoma tissues exhibited sphingosine kinase 1 expression with variable staining intensity and proportion. Thirty-four $(30.9 \%)$ of the 110 papillary thyroid carcinoma tissue samples exhibited high sphingosine kinase 1 expression. Sphingosine kinase 1 expression was observed in the cytoplasm of tumor cells; a few tumor cells with strong cytoplasmic expression also displayed weak-to-moderate nuclear sphingosine kinase immunoreactivity. Frequency of high sphingosine kinase 1 expression in papillary thyroid carcinoma was significantly higher than in nodular goiter $(p<0.001)$ or normal thyroid $(p<0.001)$ tissue.

Sphingosine kinase 1 expression and clinicopathological characteristics of papillary thyroid carcinoma. Significant correlations were observed between high sphingosine kinase 1 expression and tumor multiplicity $(p=0.004)$, extrathyroidal extension $(p=0.013)$, lymph node metastasis $(p<0.001)$, and number of metastatic lymph nodes $(p=0.042)$ (Table II). There was a marginally significant association between sphingosine kinase 1 expression and the greatest dimension of the tumor $(p=0.089)$. There was no significant association between sphingosine kinase 1 expression and patient age $(p=0.547)$, sex $(p=0.601)$, or BRAF mutational status $(p=1.000)$.

Factors independently predicting lymph node metastasis in patients with papillary thyroid carcinoma. Tumor multiplicity 
Table I. Immunohistochemical expression of sphingosine kinase 1 in normal thyroid, nodular goiter, and papillary thyroid carcinoma tissue.

\begin{tabular}{lcccc}
\hline Group & Total & \multicolumn{2}{c}{$\begin{array}{c}\text { Sphingosine kinase 1 } \\
\text { expression, n (\%) }\end{array}$} & $p$-Value \\
\cline { 2 - 4 } & & High (\%) & Low (\%) & \\
\cline { 2 - 4 } & & $0(0.0)$ & $81(100.0)$ & $<0.001 *$ \\
Normal thyroid tissue & 81 & $0(0.0)$ & $81(100.0)$ & $<0.001 *$ \\
Nodular goiter & 16 & $34(30.9)$ & $76(69.1)$ & \\
Papillary thyroid carcinoma & 110 & 34 & &
\end{tabular}

*Statistically significant.

$(p=0.027)$ and high sphingosine kinase 1 expression $(p<0.001)$ were significantly associated with lymph node metastasis (Table III). Marginally significant correlations were observed between lymph node metastasis and sex $(p=0.054)$ and extrathyroidal extension $(p=0.053)$. To identify factors that independently predict lymph node metastasis, these four covariates were entered into multivariate logistic regression analysis. We found that high sphingosine kinase 1 expression was the only independent predictive factor for lymph node metastasis $(p<0.001$, relative risk $=6.907 ; 95 \%$ confidence interval $=2.382-20.024)$. The remaining covariates - $\operatorname{sex}(p=0.064)$, tumor multiplicity $(p=0.117)$, and extrathyroidal extension $(p=0.227)$ - did not independently predict lymph node metastasis.

\section{Discussion}

In this study, we analyzed sphingosine kinase 1 expression in human papillary thyroid carcinoma. Sphingosine kinase 1 expression was significantly increased in thyroid cancer tissues compared to nodular goiter $(p<0.001)$ and normal thyroid $(p<0.001)$ tissues, consistent with previous results $(14,16,20,32-34)$. We observed that 34 (30.9\%) of 110 papillary thyroid carcinoma tissue samples had high sphingosine kinase 1 expression. These findings indicate that sphingosine kinase 1 expression is u-pregulated in papillary thyroid carcinoma and can be useful as a diagnostic biomarker for this type of carcinoma.

There have been only two previous studies of sphingosine kinase 1 expression in papillary thyroid carcinoma. Liang et al. (35) reported that overexpression of sphingosine kinase 1 differentially regulates expression of a number of microRNAs and mRNAs in the papillary thyroid carcinoma cell line, TPC1. They observed that sphingosine kinase 1 promoted cell invasion via interaction between miR-144-3p and fibronectin 1, suggesting a pro-invasive function. Guan et al. (31) reported that sphingosine kinase 1 expression in thyroid cancer is up-regulated and associated with expression of proliferating cell nuclear antigen and showed that silencing of sphingosine
Table II. Relationships between sphingosine kinase 1 expression and clinicopathological characteristics of papillary thyroid carcinoma patients.

\begin{tabular}{|c|c|c|c|c|}
\hline \multirow[t]{2}{*}{ Characteristic } & \multirow[t]{2}{*}{ Total } & \multicolumn{2}{|c|}{$\begin{array}{l}\text { Sphingosine kinase } 1 \\
\text { expression, } \mathrm{n}(\%)\end{array}$} & \multirow[t]{2}{*}{$p$-Value } \\
\hline & & High $(\%)$ & Low $(\%)$ & \\
\hline \multicolumn{5}{|l|}{ Age (years) } \\
\hline$\geq 43$ & 50 & $14(28.0)$ & $36(72.0)$ & \multirow[t]{2}{*}{0.547} \\
\hline$<43$ & 60 & $20(33.3)$ & $40(66.7)$ & \\
\hline \multicolumn{5}{|l|}{ Gender } \\
\hline Man & 35 & $12(34.3)$ & $23(65.7)$ & \multirow[t]{2}{*}{0.601} \\
\hline Woman & 75 & $22(29.3)$ & $53(70.7)$ & \\
\hline \multicolumn{5}{|c|}{ Multiplicity of tumor } \\
\hline Multiple & 26 & $14(53.8)$ & $12(46.2)$ & \multirow[t]{2}{*}{$0.004 *$} \\
\hline Single & 84 & $20(23.8)$ & $64(76.2)$ & \\
\hline \multicolumn{5}{|c|}{$\begin{array}{l}\text { Greatest dimension } \\
\text { of tumor }(\mathrm{cm})\end{array}$} \\
\hline$\geq 1.0$ & 39 & $16(41.0)$ & $23(59.0)$ & \multirow[t]{2}{*}{0.089} \\
\hline$<1.0$ & 71 & $18(25.4)$ & $53(74.6)$ & \\
\hline \multicolumn{5}{|c|}{ Extrathyroidal extension } \\
\hline Present & 55 & $23(41.8)$ & $32(58.2)$ & \multirow[t]{2}{*}{$0.013 *$} \\
\hline Absent & 55 & $11(20.0)$ & $44(80.0)$ & \\
\hline \multicolumn{5}{|c|}{ Lymph node metastasis } \\
\hline Present & 64 & $29(45.3)$ & $35(54.7)$ & \multirow[t]{2}{*}{$<0.001^{*}$} \\
\hline Absent & 46 & $5(10.9)$ & $41(89.1)$ & \\
\hline \multicolumn{5}{|c|}{$\begin{array}{l}\text { Number of lymph node } \\
\text { metastases }\end{array}$} \\
\hline$\geq 3$ & 33 & $19(57.6)$ & $14(42.4)$ & \multirow[t]{2}{*}{$0.042 *$} \\
\hline$<3$ & 31 & $10(32.3)$ & $21(67.7)$ & \\
\hline Not applicable & 46 & & & \\
\hline \multicolumn{5}{|l|}{ BRAF mutation } \\
\hline Present & 58 & $13(22.4)$ & $45(77.6)$ & \multirow[t]{3}{*}{1.000} \\
\hline Absent & 12 & $3(25.0)$ & $9(75.0)$ & \\
\hline Not applicable & 40 & & & \\
\hline
\end{tabular}

*Statistically significant.

kinase 1 suppresses proliferation of thyroid cancer cells. Other studies have shown that increased sphingosine kinase 1 expression is associated with lymph node metastasis and distant metastasis of breast cancer (36). These findings are consistent with our data showing that high sphingosine kinase 1 expression is associated with aggressive oncogenic behavior including tumor multiplicity, extrathyroidal extension, and lymph node metastasis. Our results are also consistent with studies demonstrating an association between elevated sphingosine kinase 1 expression and aggressive oncogenic behavior such as larger tumor size, deeper invasion depth, advanced stage, worse histological differentiation, higher invasiveness, and chemotherapeutic resistance in cancers of the cervix (14), head and neck (37), thyroid (31), salivary duct (32), esophagus (38), colon/rectum (39), and bladder (40).

We observed that high sphingosine kinase 1 expression was the only independent predictor of lymph node 
Table III. Factors predictive of lymph node metastasis in patients with papillary thyroid carcinoma.

\begin{tabular}{|c|c|c|c|c|c|}
\hline \multirow[t]{3}{*}{ Characteristic } & \multicolumn{3}{|c|}{ Univariate } & \multicolumn{2}{|c|}{ Multivariate } \\
\hline & \multicolumn{2}{|c|}{$\begin{array}{c}\text { Lymph node } \\
\text { metastasis, } \mathrm{n}(\%)\end{array}$} & \multirow[t]{2}{*}{$p$-Value } & \multirow[t]{2}{*}{$p$-Value } & \multirow[t]{2}{*}{$\begin{array}{c}\text { Relative risk } \\
\text { (95\% confidence interval) }\end{array}$} \\
\hline & Present & Absent & & & \\
\hline \multicolumn{6}{|l|}{ Age (years) } \\
\hline$\geq 43$ & $25(50.0)$ & $25(50.0)$ & \multirow[t]{2}{*}{0.112} & Not & Not \\
\hline$<43$ & $39(65.0)$ & $21(35.0)$ & & applicable & applicable \\
\hline \multicolumn{6}{|l|}{ Gender } \\
\hline Man & $25(71.4)$ & $10(28.6)$ & \multirow[t]{2}{*}{0.054} & \multirow[t]{2}{*}{0.064} & 0.420 \\
\hline Woman & $39(52.0)$ & $36(48.0)$ & & & $(0.167-1.052)$ \\
\hline \multicolumn{6}{|c|}{ Multiplicity of tumor } \\
\hline Multiple & $20(76.9)$ & $6(23.1)$ & \multirow[t]{2}{*}{$0.027 *$} & \multirow[t]{2}{*}{0.117} & 2.426 \\
\hline Single & $44(52.4)$ & $40(47.6)$ & & & $(0.801-7.345)$ \\
\hline \multicolumn{6}{|c|}{ Greatest dimension of tumor $(\mathrm{cm})$} \\
\hline$\geq 1.0$ & $25(64.1)$ & $14(35.9)$ & \multirow[t]{2}{*}{0.351} & \multirow{2}{*}{$\begin{array}{c}\text { Not } \\
\text { applicable }\end{array}$} & \multirow{2}{*}{$\begin{array}{c}\text { Not } \\
\text { applicable }\end{array}$} \\
\hline$<1.0$ & $39(54.9)$ & $32(45.1)$ & & & \\
\hline \multicolumn{6}{|c|}{ Extrathyroidal extension } \\
\hline Present & $37(67.3)$ & $18(32.7)$ & \multirow[t]{2}{*}{0.053} & \multirow[t]{2}{*}{0.227} & 1.723 \\
\hline Absent & $27(49.1)$ & $28(50.9)$ & & & $(0.713-4.164)$ \\
\hline \multicolumn{6}{|l|}{$B R A F$ mutation } \\
\hline Present & $33(56.9)$ & $25(43.1)$ & \multirow[t]{2}{*}{0.662} & Not & \multirow{2}{*}{$\begin{array}{c}\text { Not } \\
\text { applicable }\end{array}$} \\
\hline Absent & $6(50.0)$ & $6(50.0)$ & & applicable & \\
\hline \multicolumn{6}{|c|}{ Sphingosine kinase 1 expression } \\
\hline High & $29(85.3)$ & $5(14.7)$ & \multirow[t]{2}{*}{$<0.001 *$} & \multirow[t]{2}{*}{$<0.001^{*}$} & 6.907 \\
\hline Low & $35(46.1)$ & $41(53.9)$ & & & $(2.382-20.024)$ \\
\hline
\end{tabular}

*Statistically significant.

metastasis. Lymph node metastasis is one of the most important prognostic factors in thyroid cancer and a key determinant for predicting tumor progression and aggressive oncogenic behavior. Surprisingly, the relative risk of lymph node metastasis associated with high sphingosine kinase 1 expression (6.907) was higher than the risk associated with tumor multiplicity (2.426) or extrathyroidal extension (1.723). To the best of our knowledge, the use of sphingosine kinase 1 expression to predict lymph node metastasis has not been previously investigated. Our data suggest that sphingosine kinase 1 immunostaining provides clinically useful information for patients with papillary thyroid carcinoma, and that sphingosine kinase 1 expression is a strong predictive biomarker for identification of patients with a high risk of developing lymph node metastasis.

This study has limitations, including lack of intensive investigation of the relationship between patient outcome and sphingosine kinase 1 expression and the biological mechanisms underlying the association of sphingosine kinase 1 expression and metastasis. Further investigations into the pathogenetic mechanism and prognostic value of sphingosine kinase 1 expression in papillary thyroid carcinoma will be performed using in vitro experiments and in vivo experiments with a larger sample size and longer follow-up period.
In conclusion, we demonstrated that sphingosine kinase 1 expression is significantly upregulated in papillary thyroid carcinoma and is associated with aggressive oncogenic behavior. High sphingosine kinase 1 expression was found to be an independent factor predictive of lymph node metastasis. Our results suggest that sphingosine kinase 1 promotes progression and metastasis of thyroid cancer and can serve as a predictive biomarker for lymph node metastasis.

\section{Acknowledgements}

This research was supported by the Basic Science Research Program through the National Research Foundation of Korea (NRF) funded by the Ministry of Education (2016R1D1A1B03935584).

\section{References}

1 Hundahl SA, Cady B, Cunningham MP, Mazzaferri E, McKee RF, Rosai J, Shah JP, Fremgen AM, Stewart AK and Holzer S: Initial results from a prospective cohort study of 5583 cases of thyroid carcinoma treated in the united states during 1996. U.S. and German Thyroid Cancer Study Group. An American College of Surgeons Commission on Cancer Patient Care Evaluation study. Cancer 89: 202-217, 2000.

2 Davies L and Welch HG: Increasing incidence of thyroid cancer in the United States, 1973-2002. JAMA 295: 2164-2167, 2006. 
3 Kim HS, Lee JJ, Do SI, Kim K, Do IG, Kim DH, Chae SW and Sohn JH: Overexpression of cytokeratin 17 is associated with the development of papillary thyroid carcinoma and the presence of lymph node metastasis. Int J Clin Exp Pathol 8: 5695-5701, 2015.

4 Ito Y, Higashiyama T, Takamura Y, Miya A, Kobayashi K, Matsuzuka F, Kuma $\mathrm{K}$ and Miyauchi A: Risk factors for recurrence to the lymph node in papillary thyroid carcinoma patients without preoperatively detectable lateral node metastasis: validity of prophylactic modified radical neck dissection. World J Surg 31: 2085-2091, 2007.

5 Mercante G, Frasoldati A, Pedroni C, Formisano D, Renna L, Piana S, Gardini G, Valcavi R and Barbieri V: Prognostic factors affecting neck lymph node recurrence and distant metastasis in papillary microcarcinoma of the thyroid: results of a study in 445 patients. Thyroid 19: 707-716, 2009.

6 Moreno-Egea A, Rodriguez-Gonzalez JM, Sola-Perez J, SoriaCogollos T and Parrilla-Paricio P: Multivariate analysis of histopathological features as prognostic factors in patients with papillary thyroid carcinoma. Br J Surg 82: 1092-1094, 1995.

7 Do SI, Yoon G, Kim HS, Kim K, Lee H, Do IG, Kim DH, Chae SW and Sohn JH: Increased Brahma-related Gene 1 Expression Predicts Distant Metastasis and Shorter Survival in Patients with Invasive Ductal Carcinoma of the Breast. Anticancer Res 36: 4873-4882, 2016.

8 Tachibana M, Yoshimura H, Kinugasa S, Dhar DK, Shibakita M, Ohno S, Ueda S, Fujii T and Nagasue N: Clinicopathologic factors correlated with number of metastatic lymph nodes in oesophageal cancer. Dig Liver Dis 33: 534-538, 2001.

9 Wilson M, Rosato EL, Chojnacki KA, Chervoneva I, Kairys JC, Cohn HE, Rosato FE, Sr. and Berger AC: Prognostic significance of lymph node metastases and ratio in esophageal cancer. J Surg Res 146: 11-15, 2008.

10 Scheumann GF, Gimm O, Wegener G, Hundeshagen $\mathrm{H}$ and Dralle H: Prognostic significance and surgical management of locoregional lymph node metastases in papillary thyroid cancer. World J Surg 18: 559-567, 1994.

11 Simpson WJ, McKinney SE, Carruthers JS, Gospodarowicz MK, Sutcliffe SB and Panzarella T: Papillary and follicular thyroid cancer. Prognostic factors in 1,578 patients. Am J Med 83: 479488, 1987.

12 Mazzaferri EL and Jhiang SM: Long-term impact of initial surgical and medical therapy on papillary and follicular thyroid cancer. Am J Med 97: 418-428, 1994.

13 Nagahashi M, Ramachandran S, Kim EY, Allegood JC, Rashid OM, Yamada A, Zhao R, Milstien S, Zhou H, Spiegel S and Takabe K: Sphingosine-1-phosphate produced by sphingosine kinase 1 promotes breast cancer progression by stimulating angiogenesis and lymphangiogenesis. Cancer Res 72: 726-735, 2012.

14 Kim HS, Yoon G, Ryu JY, Cho YJ, Choi JJ, Lee YY, Kim TJ, Choi CH, Song SY, Kim BG, Bae DS and Lee JW: Sphingosine kinase 1 is a reliable prognostic factor and a novel therapeutic target for uterine cervical cancer. Oncotarget 6: 26746-26756, 2015.

15 Gault CR and Obeid LM: Still benched on its way to the bedside: sphingosine kinase 1 as an emerging target in cancer chemotherapy. Crit Rev Biochem Mol Biol 46: 342-351, 2011.

16 Li W, Yu CP, Xia JT, Zhang L, Weng GX, Zheng HQ, Kong QL, $\mathrm{Hu} \mathrm{LJ}$, Zeng MS, Zeng YX, Li M, Li J and Song LB: Sphingosine kinase 1 is associated with gastric cancer progression and poor survival of patients. Clin Cancer Res 15: 1393-1399, 2009.
17 Wymann MP and Schneiter R: Lipid signalling in disease. Nat Rev Mol Cell Biol 9: 162-176, 2008.

18 Facchinetti MM, Gandini NA, Fermento ME, Sterin-Speziale NB, Ji Y, Patel V, Gutkind JS, Rivadulla MG and Curino AC: The expression of sphingosine kinase-1 in head and neck carcinoma. Cells Tissues Organs 192: 314-324, 2010.

19 Van Brocklyn JR, Jackson CA, Pearl DK, Kotur MS, Snyder PJ and Prior TW: Sphingosine kinase-1 expression correlates with poor survival of patients with glioblastoma multiforme: roles of sphingosine kinase isoforms in growth of glioblastoma cell lines. J Neuropathol Exp Neurol 64: 695-705, 2005.

20 Li J, Guan HY, Gong LY, Song LB, Zhang N, Wu J, Yuan J, Zheng YJ, Huang ZS and $\mathrm{Li} \mathrm{M}$ : Clinical significance of sphingosine kinase-1 expression in human astrocytomas progression and overall patient survival. Clin Cancer Res 14: 6996-7003, 2008.

21 Kohno M, Momoi M, Oo ML, Paik JH, Lee YM, Venkataraman K, Ai Y, Ristimaki AP, Fyrst H, Sano H, Rosenberg D, Saba JD, Proia RL and Hla T: Intracellular role for sphingosine kinase 1 in intestinal adenoma cell proliferation. Mol Cell Biol 26: 72117223, 2006

22 Kawamori T, Kaneshiro T, Okumura M, Maalouf S, Uflacker A, Bielawski J, Hannun YA and Obeid LM: Role for sphingosine kinase 1 in colon carcinogenesis. FASEB J 23: 405-414, 2009.

23 Pyne NJ and Pyne S: Sphingosine 1-phosphate and cancer. Nat Rev Cancer 10: 489-503, 2010.

24 Johnson KR, Johnson KY, Crellin HG, Ogretmen B, Boylan AM, Harley RA and Obeid LM: Immunohistochemical distribution of sphingosine kinase 1 in normal and tumor lung tissue. J Histochem Cytochem 53: 1159-1166, 2005.

25 Pyne NJ, Tonelli F, Lim KG, Long JS, Edwards J and Pyne S: Sphingosine 1-phosphate signalling in cancer. Biochem Soc Trans 40: 94-100, 2012.

$26 \mathrm{Kim}$ EK, Yoon G and Kim HS: Chemotherapy-induced endometrial pathology: mimicry of malignancy and viral endometritis. Am J Transl Res 8: 2459-2467, 2016.

27 Yoon N, Kim JY and Kim HS: Clinical outcomes of advancedstage glassy cell carcinoma of the uterine cervix: a need for reappraisal. Oncotarget 7: 78448-78454, 2016.

28 Yoon G, Koh CW, Yoon N, Kim JY and Kim HS: Stromal p16 expression is significantly increased in endometrial carcinoma. Oncotarget 8: 4826-4836, 2017.

29 Yoon N, Yoon G, Park CK and Kim HS: Stromal p16 expression is significantly increased in malignant ovarian neoplasms. Oncotarget 7: 64665-64673, 2016.

$30 \mathrm{Na} \mathrm{K}$, Sung JY and Kim HS: Stromal p16 Overexpression in Adult Granulosa Cell Tumors of the Ovary. Anticancer Res 37: 2437-2444, 2017.

31 Guan H, Liu L, Cai J, Liu J, Ye C, Li M and Li Y: Sphingosine kinase 1 is overexpressed and promotes proliferation in human thyroid cancer. Mol Endocrinol 25: 1858-1866, 2011.

32 Liu G, Zheng H, Zhang Z, Wu Z, Xiong H, Li J and Song L: Overexpression of sphingosine kinase 1 is associated with salivary gland carcinoma progression and might be a novel predictive marker for adjuvant therapy. BMC Cancer 10: 495, 2010.

33 Malavaud B, Pchejetski D, Mazerolles C, de Paiva GR, Calvet C, Doumerc N, Pitson S, Rischmann $\mathrm{P}$ and Cuvillier $\mathrm{O}$ : Sphingosine kinase-1 activity and expression in human prostate cancer resection specimens. Eur J Cancer 46: 3417-3424, 2010. 
34 Bayerl MG, Bruggeman RD, Conroy EJ, Hengst JA, King TS, Jimenez M, Claxton DF and Yun JK: Sphingosine kinase 1 protein and mRNA are overexpressed in non-Hodgkin lymphomas and are attractive targets for novel pharmacological interventions. Leuk Lymphoma 49: 948-954, 2008.

35 Liang W, Xie Z, Cui W, Guo Y, Xu L, Wu J and Guan H: Comprehensive gene and microRNA expression profiling reveals a role for miRNAs in the oncogenic roles of SphK 1 in papillary thyroid cancer. J Cancer Res Clin Oncol 143: 601-611, 2017.

36 Zhu YJ, You H, Tan JX, Li F, Qiu Z, Li HZ, Huang HY, Zheng $\mathrm{K}$ and Ren GS: Overexpression of sphingosine kinase 1 is predictive of poor prognosis in human breast cancer. Oncol Lett 14: 63-72, 2017.

37 Tamashiro PM, Furuya H, Shimizu Y, Iino K and Kawamori T: The impact of sphingosine kinase-1 in head and neck cancer. Biomolecules 3: 481-513, 2013.

38 Pan J, Tao YF, Zhou Z, Cao BR, Wu SY, Zhang YL, Hu SY, Zhao WL, Wang J, Lou GL, Li Z, Feng $X$ and Ni J: An novel role of sphingosine kinase-1 (SPHK1) in the invasion and metastasis of esophageal carcinoma. J Transl Med 9: 157, 2011.
39 Tan SS, Khin LW, Wong L, Yan B, Ong CW, Datta A, SaltoTellez M, Lam Y and Yap CT: Sphingosine kinase 1 promotes malignant progression in colon cancer and independently predicts survival of patients with colon cancer by competing risk approach in South asian population. Clin Transl Gastroenterol 5: e51, 2014

40 Meng XD, Zhou ZS, Qiu JH, Shen WH, Wu Q and Xiao J: Increased SPHK1 expression is associated with poor prognosis in bladder cancer. Tumour Biol 35: 2075-2080, 2014.
Received August 9, 2017

Revised August 21, 2017

Accepted August 22, 2017 